\title{
НЕКОТОРЫЕ ОСОБЕННОСТИ ПРОИЗВОДСТВА ВЫЕМКИ, ПРОВОДИМОЙ ПО СУДЕБНОМУ РЕШЕНИЮ
}

\author{
И. Г. Савицкая \\ Воронежский институт МВД России \\ Поступила в редакцию 1 октября 2020 г.
}

\begin{abstract}
Аннотация: рассматриваются некоторые особенности производства выемки, предуслотренной ч. $3 \mathrm{~cm} .183$ УПК РФ, освещаются дискуссионные вопросы производства этого следственного действия, а также сфборлулированы соответствуюшие реколендации по совершенствованию уголовно-прочессуального закона. Статья проиллюстрирована прилерали из судебной практики и данныли общероссийской и региональной судебной статистики за предшествуюшие годьь.
\end{abstract}

Ключевые слова: следственнье действия, решение суда, выелка, государственная тайна, банковская тайна, ломбард.

\begin{abstract}
: the article discusses some features of the seizure procedure provided for in part 3 of article 183 of the criminal procedure code of the Russian Federation, highlights the controversial issues of this investigative action, and also makes appropriate recommendations for improving the criminal procedure law. The article is illustrated with examples from judicial practice and data from all-Russian and regional judicial statistics for previous years.
\end{abstract}

Key words: investigative actions, court decision, seizure, state secret, bank secret, pawnshop.

Производство следственных действий является основным способом собирания и проверки доказательств в процессе расследования престу$\sim$ пления и важнейшей составляющей установления истины по уголовно-

일 му делу. В ряде случаев производство некоторых следственных действий . требует дополнительного судебного контроля как важнейшей гарантии защиты конституционных прав граждан. В частности, к таким следственным действиям относятся выемка предметов и документов, содержащих государственную или иную охраняемую фредеральным законом тайну, предметов и документов, содержащих информацию о вкладах и счетах граждан в банках и иных кредитных организациях, а также вещей, заложенных или сданных на хранение в ломбард (ч. 3 ст. 183 УПК РФ). Очевидно, что информация, полученная в ходе таких следственных действий, носит ограниченный или закрытый характер, находясь под дополнительной защитой государства.

В соответствии с ч. 5 ст. 165 УПК РФ выемка предметов и документов, содержащих государственную или иную охраняемую фредеральным законом тайну, производится на основании судебного решения и не относится к следственным действиям, которые можно произвести только на основании постановления следователя (дознавателя) в случаях, не тер-

(С Савицкая И. Г., 2021 
пящих отлагательства. Выемка таких сведений может производиться, например, в учреждениях налоговой инспекции, медицинских и иных государственных организациях.

Так, в ходе предварительного следствия по уголовному делу по фракту совершения преступления, предусмотренного п. «а», «б» ч. 4 ст. 171.1 УК РФ было установлено, что в МИФНС № 12 по Воронежской области, расположенной по адресу: г. Воронеж, ул. К. Маркса, д. 46, находятся документы, содержащие иную охраняемую законом тайну, подтверждающие государственную регистрацию ООО «ВРТ» (ИНН 3663065921) в качестве юридического лица, которые могут служить средством к установлению обстоятельств уголовного дела. Проверив представленные материалы, обосновывающие постановление следователя, судья заявленное ходатайство удовлетворил ${ }^{1}$. В ходе предварительного следствия по другому уголовному делу, по признакам преступления, предусмотренного п. «в» ч. 2 ст. 158 УК РФ было установлено, что подозреваемый К. находился на стационарном лечении в КУЗ «Воронежский областной клинический психоневрологический диспансер». В связи с необходимостью проведения психолого-психиатрической судебной экспертизы в отношении подозреваемого К. потребовалось предоставление его медицинской карты (иная охраняемая законом тайна), в связи с чем следователь возбудил перед судом ходатайство о производстве выемки в КУЗ «ВОКПНД» медицинской карты стационарного больного К., которое было удовлетворено судом²

Сведения, содержащие государственную или иную охраняемую федеральным законом тайну, можно обнаружить и в ходе проведения обыска, который, согласно ч. 5 ст. 165 УПК РФ, может быть произведен в исключительных случаях без получения судебного решения. Примечательно, что провести обыск без судебного решения можно, а вот изъять обнаруженные в ходе обыска предметы и документы, содержащие государственную или иную охраняемую федеральным законом тайну, нельзя. На такой законодательный казус указывают многие авторы ${ }^{3}$, при этом УПК РФ не предусматривает возможность производства иных следственных действий, направленных на изъятие таких сведений ${ }^{4}$. Согласно постановлению Конституционного Суда РФ «недопустимо без судебного решения изымать сведения, составляющие охраняемую федеральным законом тайну, обнаруженные в ходе производства обыска в нежилом помещении, а в некоторых случаях - и в жилом, если речь идет об адвокатской тайне» ${ }^{5}$.На практике такая позиция законодателя и Конституционного

${ }^{1}$ Уголовное дело № 3/7-11/19 // Архив Советского районного суда г. Воронежа.

2 Там же.

${ }^{3}$ См.: Терехов М. Ю., Ерохина О. С. Некоторые проблемы производства следственных действий при получении сведений, составляющих охраняемую федеральным законом тайну // Вестник Уральского юрид. ин-та МВД России. 2016. № 2. C. $10-12$.

${ }^{4}$ См.: Григорьев В. Н., Терехов М. Ю. Особенности получения органами предварительного расследования сведений, составляющих государственную или иную охраняемую федеральным законом тайну (на примере деятельности органов внутренних дел). Домодедово, 2013.

${ }^{5}$ По делу о проверке конституционности пункта 7 части второй статьи 29 , части четвертой статьи 165 и части первой статьи 182 Уголовно-процессуального ко- 


\section{Вестник ВГУ. Серия: Право}

Суда РФ означает, что пока следователь (дознаватель) будет получать судебное разрешение на производство выемки предметов и документов, составляющих охраняемую федеральным законом тайну, обнаруженных в процессе производства обыска, заинтересованные лица могут скрыть или уничтожить важнейшие доказательства, имеющие значение для уголовного дела. Исходя из этого, представляется необходимым предусмотреть в уголовно-процессуальном законе порядок производства следственных действий, в ходе которых возможно получить сведения, составляющие охраняемую федеральным законом тайну.

Одним из наиболее распространенных следственных действий, проводимых при расследовании преступлений, совершаемых в сфере экономики, является выемка документов в банках и иных кредитных организациях (ч. 3 ст. 183 УПК РФ). Сводные статистические сведения о деятельности федеральных судов общей юрисдикции за предыдущие пять лет свидетельствуют о достаточно частом производстве таких следственных действий в ходе производства по уголовным делам как в целом по России ${ }^{6}$, так и в отдельных регионах (на примере Воронежской области) ${ }^{7}$ (табл. 1).

Т а б ли ц а 1

Число ходатайств о производстве выелки предметов и документов, содержащих инфбормацию о вкладах и счетах в банках и иных кредитных организащиях (n. 7 ч. $2 \mathrm{~cm} .29$ УПК РФ), расслотренных судами общей юрисдикиии РФ в ходе досудебного производства (2015 - 2019 гг.)

\begin{tabular}{|c|c|c|c|c|c|c|c|}
\hline \multirow{3}{*}{$\begin{array}{l}\sim \\
\text { 익 }\end{array}$} & \multirow{2}{*}{ Год } & \multicolumn{2}{|c|}{ Всего поступило } & \multicolumn{2}{|c|}{ У довлетворено } & \multicolumn{2}{|c|}{$\begin{array}{c}\text { Отказано } \\
\text { в удовлетворении }\end{array}$} \\
\hline & & по РФ & $\begin{array}{l}\text { по Воронеж- } \\
\text { ской области }\end{array}$ & по РФ & $\begin{array}{l}\text { по Воронеж- } \\
\text { ской области }\end{array}$ & по РФ & $\begin{array}{l}\text { по Воронеж- } \\
\text { ской области }\end{array}$ \\
\hline & 2015 & 80656 & 2845 & 78444 & 2780 & 1584 & 24 \\
\hline \multirow{4}{*}{ ্ָণ } & 2016 & 78461 & 3555 & 76310 & 3489 & 1538 & 56 \\
\hline & 2017 & 68872 & 3201 & 66764 & 3149 & 1360 & 35 \\
\hline & 2018 & 65034 & 2190 & 62678 & 2142 & 1168 & 30 \\
\hline & 2019 & 65536 & 2045 & 65526 & 1986 & 1041 & 47 \\
\hline
\end{tabular}

К банковским документам кредитной организации, подлежащим выемке, могут относиться различные заявления, платежные документы,

декса Российской Федерации в связи с жалобой граждан А. В. Баляна, М. С. Дзюбы и других : постановление Конституционного Суда РФ от 17 декабря 2015 г. № 33- П. Доступ из справ.-правовой системы «КонсультантПлюс».

${ }^{6}$ Сводные статистические сведения о деятельности фредеральных судов общей юрисдикции в период с 2015 по 2019 г. / Статистика Судебного департамента при Верховном Суде РФ. URL: http: //www.cdep.ru (дата обращения: 24.09.2020).

${ }^{7}$ Сводные статистические сведения о деятельности федеральных судов общей юрисдикции Воронежской области в период с 2015 по 2019 г / Статистика Управления Судебного департамента в Воронежской области. URL: http://usd.vrn.sudrf. ru (дата обращения: 24.09.2020). 
справки по операциям и счетам, договоры об открытии и закрытии счетов, паспорта внешнеэкономических сделок, карточки с образцами подписей руководителя и главного бухгалтера, а также иные документы, содержащие подписи ответственных лиц. Выемка таких документов часто связана с вопросами соблюдения банковской тайны, которой считается «тайна об операциях, о счетах и вкладах своих клиентов и корреспондентов» ${ }^{8}$, вследствие чего она может быть произведена только на основании судебного решения, полученного в порядке ст. 165 УПК РФ, даже в исключительных случаях.

Так, в ходе расследования уголовного дела по признакам преступления, предусмотренного п. «в» ч. 3 ст. 158 УК РФ, судом было удовлетворено ходатайство следователя на производство выемки в ООО Коммерческий банк «Адмиралтейский» оригиналов денежных чеков, поскольку указанные документы содержали информацию о движении денежных средств по счету подозреваемого и имели доказательственное значение для уголовного дела ${ }^{9}$.

В ходе предварительного следствия по уголовному делу по признакам преступления, предусмотренного ч. 4 ст. 111 УК РФ (в квартире были обнаружены два трупа с гнилостными изменениями), было установлено, что автомобиль погибшего К. был перерегистрирован на имя свидетеля, при этом договор купли-продажи самим К. не подписывался. Следствие установило, что у погибшего К. были открыты банковские счета в отделении ПАО «Сбербанк». По ходатайству следователя суд разрешил производство выемки в отделении ПАО «Сбербанк» для изъятия документов погибшего К., содержащих свободные образцы его подписи, так как указанные сведения могут иметь значение по данному уголовному делу ${ }^{10}$.

Следует отметить, что информацию о движении средств по счетам организации или в банке следователь может получить на основании письменного запроса, при наличии согласия руководителя следственного органа (ст. 26 Федерального закона «О банках и банковской деятельности»). Если требуются иные вышеуказанные документы, то производится выемка.

Ряд авторов, например С. В. Ермаков, М. М Макаренко, обращают внимание на несовершенство положений ч. 3 ст. 183 УПК РФ. Так, в формулировке предложения «о выемке предметов и документов, содержащих информацию о вкладах и счетах «граждан», законодателем не упоминается информация о вкладах и счетах «организаций». Следует согласиться с указанными авторами, что такая неясность может сформировать у следователя неверное представление о том, что выемка, содержащая информацию о вкладах и счетах «организаций», в отличие от информации о вкладах и счетах «граждан», не требует судебного решения ${ }^{11}$.

8 О банках и банковской деятельности : федер. закон от 2 декабря 1990 г. № 395-I // Ведомости съезда народных депутатов РСФСР. 1990. № 27. Ст. 357. Доступ из справ.-правовой системы «КонсультантПлюс».

${ }_{9}^{9}$ Уголовное дело № 3/7-94/2015 // Архив Советского районного суда г. Воронежа.

10 Уголовное дело № 3/7-317/2017 // Архив Советского районного суда г. Воронежа.

${ }^{11}$ См.: Ерлаков С. В., Макаренко М. М. Проблемы производства выемки документов, содержащих налоговую и банковскую тайну // Вестник Моск. ун-та МВД России. М., 2013. № 7. С. 92-94. 


\section{Вестник ВГУ. Серия: Право}

Представляется целесообразным устранить такой пробел, дополнив ч. 3 ст. 183 УПК РФ соответствующим образом.

Достаточно часто имущество, добытое преступным путем, закладывается в ломбард, в связи с чем возникает необходимость его изъятия посредством производства выемки. Указанное подтверждается и официальными данными судебной статистики (табл. 2).

Т а б ли ц а 2

Число ходатайств о производстве выелки заложенной или сданной на хранение в лолбард вещи (n. 5.1 ч. 2 cm. 29 УПК РФ), расслотренных судали общей юрисдикиии РФ в ходе досудебного производства (2016-2019 ге.)

\begin{tabular}{|c|c|c|c|c|c|c|}
\hline \multirow{2}{*}{ Год } & \multicolumn{2}{|c|}{ Всего поступило } & \multicolumn{2}{|c|}{ Удовлетворено } & \multicolumn{2}{|c|}{$\begin{array}{l}\text { Отказано } \\
\text { в удовлетворении }\end{array}$} \\
\cline { 2 - 7 } & по РФ & $\begin{array}{l}\text { по Воронеж- } \\
\text { ской области }\end{array}$ & по РФ & $\begin{array}{c}\text { по Воронеж- } \\
\text { ской области }\end{array}$ & по РФ & $\begin{array}{c}\text { по Воронеж- } \\
\text { ской области }\end{array}$ \\
\hline 2016 & 4017 & 53 & 3922 & 50 & 62 & 2 \\
\hline 2017 & 6508 & 214 & 6349 & 211 & 79 & 1 \\
\hline 2018 & 5251 & 153 & 5112 & 152 & 70 & 1 \\
\hline 2019 & 4546 & 123 & 4379 & 121 & 67 & 2 \\
\hline
\end{tabular}

В соответствии со ст. 2 Федерального закона «О ломбардах» основными видами деятельности ломбарда являются предоставление краткосрочных займов гражданам и хранение вещей ${ }^{12}$.

Фактическим основанием для производства следователем (дознавателем) выемки в ломбарде является наличие достаточных данных, указывающих, что в нем или в его территориально обособленном подразделении находится определенный предмет или документ, имеющий значение для уголовного дела. Такие данные могут подтверждаться, как 을 присутствующими в деле доказательствами (например, показаниями подозреваемого или свидетеля о том, что похищенная вещь или предмет заложены в ломбард ${ }^{13}$; изъятым в ходе личного обыска залоговым билетом, подтверждающим фракт сдачи предмета или вещи в ломбард $\left.{ }^{14}\right)$, так и результатами оперативно-розыскной деятельности, предоставлен236 ными следователю (дознавателю) в установленном законом порядке ${ }^{15}$ и

12 О ломбардах : федер. закон от 19 июля 2007 г. № 196-ФЗ (с изм. и доп.) // Собр. законодательства Рос. Федерации. 2007. № 31. Ст. 3992.

${ }^{13}$ Кассационное определение Верховного Суда РФ от 27 мая 2010 г. № 14-010-28. Доступ из справ.-правовой системы «КонсультантПлюс».

14 Кассационное определение Верховного Суда РФ от 14 декабря 2005 г. № 5-О05-185. Доступ из справ.-правовой системы «КонсультантПлюс».

${ }^{15}$ Об утверждении Инструкции о порядке представления результатов оперативно-розыскной деятельности органу дознания, следователю или в суд : приказ МВД России, Министерства обороны РФ, ФСБ России, Федеральной службы охраны РФ, Федеральной таможенной службы, Службы внешней разведки РФ, Федеральной службы исполнения наказаний, Федеральной службы РФ по контролю 
подтверждающими фракт нахождения вещи, предмета или документа в ломбарде.

Выемка из ломбарда вещи, заложенной или сданной на хранение, производится в порядке, предусмотренном ст. 165 УПК РФ, и требует постановления суда, а в исключительных случаях, не терпящих отлагательства - на основании постановления следователя (дознавателя) (ч. 5 ст. 165 УПК РФ).

В связи с тем что ломбард - это юридическое лицо, юрисдикция судебного решения может не распространяться на его обособленные подразделения, поэтому при подготовке постановления о возбуждении перед судом ходатайства о выемке следователю (дознавателю) необходимо указать адрес конкретного территориально обособленного подразделения ломбарда, где находится вещь, которую необходимо изъять ${ }^{16}$. Кроме того, в постановлении о возбуждении ходатайства для производства выемки из ломбарда заложенной или сданной на хранение вещи необходимо указать:

- наименование и ее идентифицирующие признаки (форму, размер, вес, пробу золота, особые приметы ${ }^{17}$ ), которые, как правило, указываются в залоговом билете или квитанции. В случае отсутствия таких документов, информащию об интересующей вещи можно получить в ходе допроса лица, предложив ему выполнить эскиз искомой вещи ${ }^{18}$;

- точное местонахождение вещи в помещении ломбарда ${ }^{19}$;

Так, по уголовному делу по признакам преступления, предусмотренного п. «в» ч. 2 ст. 158 УК РФ, в ходе допроса подозреваемого П. было установлено, что похищенные золотые изделия: два золотых кольца, пару золотых серег, золотую цепь и кулон он сдал согласно залоговым билетам в ООО «Городской ломбард», предъявив паспорт на свое имя. В целях изъятия вещественных доказательств, которые являются предметами преступного посягательства, следователем было возбуждено ходатайство перед судом об изъятии их из ломбарда ${ }^{20}$.

В ходе расследования по уголовному делу, возбужденному по признакам преступления, предусмотренного п. «б», «в» ч. 2 ст. 158 УК РФ, потерпевший в ходе допроса пояснил, что среди похищенного у него имущества находился штроборез Messer c серийным номером 002593. Допрошенный в качестве свидетеля сотруд-

за оборотом наркотиков, Следственного комитета РФ от 27 сентября 2013 г. № 77 6/703/509/507/1820/42/535/398/68 // Рос. газета. 2013. 13 дек.

${ }^{16}$ См.: Пилюшин И. П. Основания и порядок производства следственных действий в ломбарде // Законодательство и практика. 2014. № 1. С. 58-61.

17 Апелляционное определение Томского областного суда от 18 марта 2013 г. № 22-1296/2013 7. Доступ из справ.-правовой системы «КонсультантПлюс».

1818 Кассационное определение Верховного Суда РФ от 31 августа 2005 г. № 11-005-55 8. Доступ из справ.-правовой системы «КонсультантПлюс».

${ }^{19}$ Справка по результатам обобщения судебной практики рассмотрения Соломбальским районным судом г. Архангельска в первом полугодии 2012 г. ходатайств о производстве следственных действий. Доступ из справ.-правовой системы «КонсультантПлюс».

${ }^{20}$ Уголовное дело № 3/14-18/2018 // Архив Советского районного суда г. Воронежа. 


\section{Вестник ВГУ. Серия: Право}

ник ООО «Ломбард Фортуна» рассказал, что в день кражи в ООО «Ломбард Фортуна» был сдан штроборез Messer с серийным номером 002593, помещенный на ответственное хранение. Проверив представленные материалы, суд удовлетворил ходатайство следователя о выемке из ломбарда, поскольку штроборез Messer с серийным номером 002593 является предметом преступного посягательства ${ }^{21}$.

К постановлению о возбуждении перед судом ходатайства о производстве выемки вещей, заложенных или сданных на хранение в ломбард, следователю необходимо приобщить соответствующие материалы (копии протоколов допроса, иных следственных действий, результаты оперативно-розыскной деятельности), обосновывающие необходимость ее производства.

В обязательном порядке получение судебного решения требуется в случаях, когда необходимо изъять документы, содержащие информацию, составляющую профессиональную тайну при осуществлении ломбардом своей деятельности ${ }^{22}$ (информация, полученная ломбардом от заемщика или поклажедателя в связи с заключением договора займа или договора хранения, отраженная в залоговом билете, и именная сохранная квитанция) $)^{23}$.

В отличие от выемки предметов и документов, содержащих государственную или иную охраняемую федеральным законом тайну, а также предметов и документов, содержащих информацию о вкладах и счетах граждан в банках и иных кредитных организациях, выемка в ломбарде может быть произведена на основании постановления следователя (дознавателя) без судебного решения в исключительных случаях (ч. 5 ст. 165 УПК РФ). Перечень исключительных случаев УПК РФ не регламентирован, однако представляется, что такими могут быть случаи, когда:

- в документах, подлежащих изъятию, не содержится информация,

составляющая профессиональную тайну при осуществлении ломбардом 이르는 деятельности;

- заемщик собирается забрать вещь из ломбарда;

- ломбард может продать вещь в связи с истечением срока возврата суммы предоставленного займа;

- вещь не является заложенной или сданной на хранение. В соответствии со ст. 3 Федерального закона «О ломбардах» ${ }^{24}$ информация о такой вещи не относится к профессиональной тайне осуществления ломбардом своей деятельности;

${ }^{21}$ Уголовное дело № 3/15-13/2019 // Архив Советского районного суда г. Воронежа.

22 Постановление о разрешении производства выемки Миякинского районного суда Республики Башкортостан № 3/3-7/2012. Доступ из справ.-правовой системы «КонсультантПлюс».

${ }^{23}$ Кассационное определение Верховного Суда РФ от 31 августа 2005 г. № 11005-55. Доступ из справ.-правовой системы «КонсультантПлюс».

${ }^{24}$ О ломбардах : федер. закон от 19 июля 2007 г. № 196-ФЗ // Собр. законодательства Рос. Федерации. 2007. № 31. Ст. 3992. 
- вещь является невостребованной. По истечении льготного срока, установленного законом, заемщик не исполнил обязательство, предусмотренное договором займа, или не забрал сданную на хранение вещь (ст. 12 Федерального закона «О ломбардах»).

Вышеуказанные исключительные случаи должны быть отражены в постановлении следователя о производстве выемки.

Вопрос о производстве обыска в ломбарде является в юридической науке дискуссионным, а на практике решается неоднозначно. Так, с одной стороны, можно привести примеры прекращения производства судами по ходатайствам следователя о проведении обыска в ломбарде в связи с отсутствием законодательного порядка его производства ${ }^{25}$ или в связи с полномочиями на дачу разрешения производства обыска только в жилище ${ }^{26}$.

С другой стороны, представляется, что возможность производства обыска в ломбарде продиктована современными реалиями, подтверждается и практической деятельностью правоохранительных органов, а также не противоречит ч. 1 ст. 182 УПК РФ, которая устанавливает, что обыск «производится, если имеются достаточные данные полагать, что в каком-либо месте находятся орудия преступления, предметы, документы и ценности, которые могут иметь значение для уголовного дела» ${ }^{27}$. В связи с этим представляется необходимым внести в ст. 182 УПК РФ изменения, предусматривающие возможность производства обыска в ломбарде, дополнив ее соответствующими положениями.

\section{Библиографический список}

Григорьев В. Н., Терехов М. Ю. Особенности получения органами предварительного расследования сведений, составляющих государственную или иную охраняемую федеральным законом тайну (на примере деятельности органов внутренних дел). Домодедово : ВИПК МВД России, 2013. 110 с.

Ерлаков С. В., Макаренко М. М. Проблемы производства выемки документов, содержащих налоговую и банковскую тайну // Вестник Моск. ун-та МВД России. 2013. № 7. С. 92-94.

Пилюшин И. П. Основания и порядок производства следственных действий в ломбарде // Законодательство и практика. 2014. № 1. С. 58-61.

Терехов М. Ю., Ерохина О. С. Некоторые проблемы производства следственных действий при получении сведений, составляющих охраняемую фе-

25 Кассационное определение Верховного Суда Республики Татарстан от 10 февраля 2009 г. : постановление судьи Советского районного суда г. Казани от 26 декабря 2008 г. об отказе в удовлетворении ходатайства следователя СУ при УВД Советского района г. Казани о производстве обыска в ломбарде. Доступ из справ.-правовой системы «КонсультантПлюс».

${ }^{26}$ Кассационное определение Иркутского областного суда от 29 апреля 2011 г. № 22-1663/11. Доступ из справ.-правовой системы «КонсультантПлюс».

27 Кассационные определения Верховного Суда РФ: от 21 августа 2002 г. № 5-о02-126 ; от 31 августа 2005 г. № 11-005-55; от 13 ноября 2006 г. № 9-о06-57 ; от 21 июня 2012 г. № 11-О12-35. Доступ из справ.-правовой системы «КонсультантПлюс». 
деральным законом тайну // Вестник Уральского юрид. ин-та МВД России. 2016. № 2. C. 10-12.

\section{References}

Grigoriev V. N., Terekhov M. Yu. Features of obtaining by preliminary investigation bodies of information constituting a state or other secret protected by Federal law (on the example of the activities of internal Affairs bodies). Domodedovo : VIPK MVD of Russia, 2013. 110 p.

Ermakov S. V., Makarenko M. M. Problems of production of seizure of documents containing tax and Bank secrecy // Bulletin of the Moscow University of the Ministry of internal Affairs of Russia. 2013. No. 7. P. 92-94.

Pilyushin I. P. Grounds and procedure for investigative actions in a pawnshop // Legislation and practice. 2014. No. 1. P. 58-61.

Terekhov M. Yu., Erokhina O. S. Some problems of investigative actions in obtaining information that is a secret protected by Federal law // Bulletin of the Ural law Institute of the Ministry of internal Affairs of Russia. 2016. No. 2. P. 10-12.

Воронежский институт МВД России

Савиикая И. Г., кандидат юридических наук, дочент кафедры уголовного проиесса

E-mail: arisha_s@list.ru
Voronezh Institute of the Russian Ministry of Internal Affairs

Savitskaya I. G., Candidate of Legal Sciences, Associate Professor of the Criminal Process Department

E-mail:arisha_s@list.ru 